\title{
Island Constraints in English and Kurdish
}

\author{
Burhan Qadir Saleem \\ English Department, College of Basic Education, University of Raparin, Rania, Kurdistan Region, \\ Iraq. \\ E-mail: burhan@uor.edu.krd
}

\begin{abstract}
:
In transformational grammar, there are rules such as relativization, questioning and topicalization, in which elements abandon their position and move to the front of the sentence. The present study focusses on certain islands in English and Kurdish and examines whether these islands constrain the extraction of elements in Kurdish or not. It is hypothesized that islandhood is not only bout the restrictions on the extraction of an element and putting it in front of the sentence. In Kurdish, even if the question word remains in-situ, there are islands that impose restrictions on forming structures such as interrogatives.
\end{abstract}

Keywords: Complex NP Islands, Sentential Subject Constraint, Left Branch Condition, Coordinate Structure Constraint, Adjunct Clause Constraint, Indirect Wh-Question Constraint. 


\section{Introduction:}

Imagine that you are on an island that abounds with different types of fruit, but without any means of transport for exporting the fruits; they are locally usable (only on the island). And imagine that you are trying to export the fruits in a leftward direction but all the attempts will be abortive. Why? Because the island is surrounded by the sea that has huge waves forming the biggest obstacle to exporting the fruits. Chomsky in 1964, discovered the island and observed the waves (= restrictions) in front of the export (= displacement) operations known as A-bar movement or extraction. Ross's thesis (1967) moves around Chomsky's proposal shedding light on the weakness and strength of his proposal. Ross (1967) states that Chomsky's A-over-A hypothesis is too strong about the extraction of a noun inside a bigger noun phrase:

1) a. Which news did you read [a newspaper about ] ?

On the other hand, Chomsky's A-over-A theory does not say anything about the extraction of the adjective phrase from the noun phrase in (2c).

2) a. She has got a very handsome boyfriend.

b. How handsome a boyfriend has she got?

c. *How handsome has she got [a boyfriend]? (Boeckx, 2010: 5)

Later, Ross in (1967) noticed that it is the nature and structure of the islands that do not permit elements inside themselves to be exported or extracted to somewhere else outside them. Now let us leave our imaginary island and come to the Ross's real syntactic islands.

\section{Complex NP Constraint (Complex NP-islands) (CNPC):}

Before talking about the islands, consider the following examples:

3) a) Jane was dating $<$ Tom $>$.

b) Jane was dating $<$ who $>$. (Deep structure)

c) $<$ Who $>$ was Jane dating? (Surface structure)

Examples (3a-c) show that wh-movement is grammatically acceptable, in which a declarative sentence was changed to an interrogative one in force. Now we have an island that can epitomize the syntactic island constraints. So the CNPC is that phrase to which a clause is a complement.

4) a) Clare believed Jane was dating $\langle$ Tom $\rangle$.

b) < Who> did Clare believe Jane was dating?

5) a) Clare believed Jane who was dating $<$ Tom $>$.

b) $*<$ Who $>$ did Clare believe Jane who was dating

6) a) I saw < the man who talked about you $>$

b) $*$ Who did you see $<$ the man who talked about $>$ ? 
The complex NP the man who talked about you in (6a) is that imaginary island that you are on. You is the fruit (element) that cannot be extracted from the island and it is only usable inside the complex NP. The obstacles formed by the waves are called constraints. In (7), the $\mathrm{x}$ on the arrow elucidates that John is constrained from being whquestioned.

7)

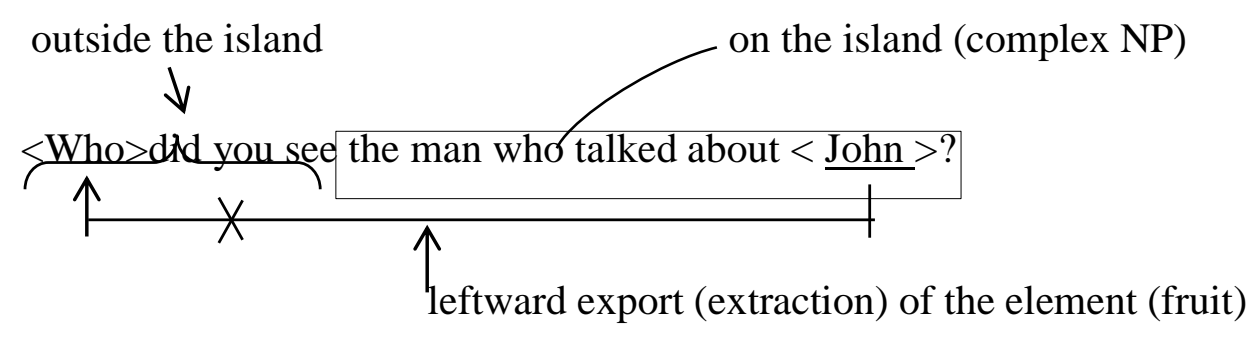

Ross (1967: 119) argues that "elements dominated by a sentence which is dominated by a noun phrase cannot be questioned or relativized." Consider the following example:

8) a) He concealed [NP the fact [CP that she murdered her husband].

The idea is that any element inside the CP that she murdered her husband (which Ross refers to as a sentence) is not allowed to be extracted because the CP is dominated by the NP the fact.

b) *Who did he conceal [NP the fact [CP that she murdered ?]

c) *Who did he conceal [NP the fact [CP that__ murdered her husband?]

d) *What did he conceal [NP the fact [CP that she her husband?]

Ross's claim can be restated as what Kim and Sells (2007: 242) state: "A CP dominating any NP has a gap value, but an NP dominating a CP does not have a gap value". Now consider sentences $(9 \mathrm{a} \& \mathrm{~b})$ :

9) a) The government proposed [CP that they change the voting system].

b) The government proposed [NP a motion [CP that they change the voting system].

The difference between the NP the voting system in (9a) and the NP the voting system in (9b) is that the NP in (9a) is a constituent of a clause functioning as direct object of the verb proposed. A clause functioning as object of a verb has a gap value, i.e. in wh-interrogatives; the clause allows its constituents to be extracted. Accordingly, the CP of (9a) is not an island.

c) $<$ What $>$ did the government propose [that they change $<$ $>$ ?]

On the other hand, the NP the voting system in (9b) is a constituent of (dominated by) a CP which is again dominated by another NP, namely a motion. The whole structure a motion that they should change the voting system forms a complex NP island. Thus, the NP the voting system cannot be wh-questioned:

d) $*<$ What $>$ did the government propose [CNP a motion that they change $<$ $>]$ ? 
To understand what CNP is, Featherston (2001: 65) simply names it sentences containing relative clauses. The constraint is also imposed on the nominal head a motion; it cannot be extracted out of complex NP because it is a constituent of the whole complex NP structure.

e) *What did the government propose [NP [CP that they change the voting system?]

Only the extraction of the whole complex NP is grammatical, this is because the complex NP serves the function of being the complement (direct object) of the verb propose:

f) What did the government propose [ ] ?

In the process of topicalization, the complex NP $(\mathrm{CNP})$ does not permit the extraction either:

10) a) I have [CNP two friends who like Jack]

b) As for Jack, I have [cNP two friends who like him].

c) *Jack, I have [cNp two friends who like _ ]. (Goodluck, 1992: 3)

All the above examples of CNP functioned as direct object. Even if it functions as subject, it still remains as an island because islandhood, which is being discussed here, is about the structure not function (Frank, 2002:104). For island constraints based on grammatical functions, see Kaplan and Zaenen (1989) and Heck (2008).

11) a) [NP The tests [CP that <the water > contains high levels of pollutants] worried environmentalists.

\section{Sentential Subject Constraint (SSC):}

Ross (1967: 243) points out that "no element dominated by an S may be moved out of that $\mathrm{S}$ if that node $\mathrm{S}$ is dominated by an NP which itself is immediately dominated by S." This type of island is a clausal subject within which an element is not allowed to be wh-questioned or relativized (= extracted).

12) a) [That the government promotes your salary] is a blatantly fat lie.

b) *What is [that the government promotes _ _ a blatantly fat lie?

c) *Who is [that ___ promotes your salary] a blatantly fat lie?

Consider the following that-clauses in the sentences below:

13) a) Adam believed [that the government would promote his salary].

b) It was believed by Adam [that the government would promote his salary].

c) [That the government would promote his salary] was believed by the employee.

Sentences (13b \& c) are passives of (13a). Noun phrases in that-clauses of (13a \& b) can be extracted because they do not function as subject. On the other hand, no element in the that-clause of sentence (13c) is allowed to be extracted. In the introduction it was stated that 'the elements are locally usable (only on the island), it is necessary 
to clarify the statement. The that-clause of sentence (13c) is a sentential (= clausal) subject island on which the elements can be locally reordered only; the elements of the clause can be passivized locally:

d) [That his salaries would be promoted by the government] was believed by the employee.

Even by reordering the elements of the sentences (13a, b and c), we can get the following:

14) a) The salary which the employee believed that the government would promote is a pipedream.

b) The salary which was believed by the employee that the government would promote is a pipedream.

c) $*<$ His salary which $>$ that the government would promote $<\quad>$ was believed by the employee is a pipedream.

Although, in each of the sentences (13a, b and c), the noun phrase his salary is the object of the verb promote, the verb promote of sentences (14a and b) is in those that-clauses which function as the objects of the verb believed. While the noun phrase his salary and the verb promote of (13c) are in a that-clause which functions as the subject of the sentence.

\section{Left Branch Condition (LBC):}

This island is an NP which is divided into left and right branches, each branch is an NP. The movement of the left branch is hampered from movement.

15) a) Jack broke the glass of $\langle$ the window $>$.

b) What did Jack break the glass of $<$ $>$ ?

The window is the right branch of the NP and the movement of this one is grammatical, but the left branch is not allowed as explained in the following example.

c) Jack broke <the glass $>$ of the window.

d) *What did Jack break < _ > of the window?

Radford (2004: 217-18) states that LBC gives an explanation of the ungrammaticality of structures whose leftmost constituent cannot be extracted out of it. He adds that the structures are not only noun phrases but adjectival and adverbial phrases.

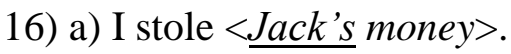

b) *Whose did you steal < money $>$ ?

17) a) She was < very glad of her warm coat> in the biting wind.

b) *How was she < _ glad of her warm coat> in the biting wind?

18) a) He plays football < $\underline{\text { very }}$ well> .

b) *How does he play football < well>? 
LBC hampers or blocks the movement of whose and how on their own. To make the interrogative sentences grammatically well-formed, the Convergence Principle is the solution. It is a UG principle by means of which the next smallest constituent containing whose or how is preposed. The next smallest constituent means the only sufficient material is moved along with whose or how for the sake of convergence (= grammaticality). The resulting derivation will be convergent, i.e. it does not go against any syntactic constraints. Accordingly, the sentences (16b, $17 \mathrm{~b}$, and $18 \mathrm{~b})$ are reformulated as $(19,20$, and 21$)$ below:

19) Whose money did you steal < >?

20) How glad was she < of her warm coat> in the biting wind?

21) How well does he play football < >? (Radford, 2004: 111)

\section{Coordinate Structure Constraint (CSC)}

A coordinate structure, as Newson et al (2006: 82) point out, is that one in which two elements by means of a coordinator are strung together from which a single element is formed. This formed element functions like the two former elements that have had or would have separately. Here, the main focus is on the central coordinators: and and $o r$.

22) Jack and Jane had dinner in the new restaurant.

The structure consists of at least two conjucts namely Jack and Jane put together by means of the coordinator and. The conjucts once again can consist of different grammatically hierarchical structure; they can be words as in (22), phrases as in (23a), or even clauses as in (23b). They can also appear as subject, object, complement, etc.

23) a) My uncle and Jane's mother got married in 2000.

b) Jack studies at university and Jane works for an airline.

Ross (1967: 161) makes a claim that neither conjunct alone, nor any element contained in the conjunct may be moved out of that conjunct. In other words, neither a conjunct can be a gap alone, nor can the conjunct contain a gap if its antecedent (= filler) is moved outside that conjunct.

24) Tom washed the dishes and Lily dried them.

*What did Tom wash and Lily dried them?

*What did Tom do and Lily dried them?

*What did Lily dry and Tom washed the dishes?

*What did Lily do and Tom washed the dishes?

But when a coordinate structure is a constituent of a relative clause or that-clause, there may be exceptions that can easily violate the island constraint:

25) This is the tennis player that [we got [the signature of and two rackets of]].

Sag and Wasow (1999: 359) are of the view that (25), which is a violation called 'Across-the-Board' Exception, is only a complicated addendum that Ross added to (CSC). They might be true because, firstly, a relative or that-clause 
can allow its elements to be extracted. And secondly, (25) can be reordered as (26a) in which the coordinate structure the signature and two rackets is a case of Left Branch Condition which cannot be wh-questioned:

26) a) We got the signature and two rackets of this tennis player.

b) $*<$ What $>$ did you get $<$ $>$ of this tennis player?

Another point to be raised is that even a coordinator, either with a conjunct or without it, cannot leave a gap because it is a part or element of the second conjunct as Quirck et al (1985: 921) exemplify:

27) a) Maybe, it is my imagination or Jane is behaving strangely at the moment.

b) Is it my imagination or is Jane behaving strangely at the moment?

c)*Or is Jane behaving strangely at the moment, it is my imagination?

d)*Or is it my imagination, is Jane behaving strangely at the moment?

And Ross gives a reason for this point stating that if a conjoined sentence is broken into two separate sentences, the coordinator never goes with the first sentence:

28) a) Jessamine arrived, and she didn't even say hello.

b) Jessamine arrived. And she didn't even say hello.

c) *Jessamine arrived and. She didn’t even say hello.

\section{Adjunct Clause Constraint}

Adjunct clauses which are also known as adverbial clauses include: clauses of reason, concession, time, place, purpose and condition. The following are consecutive examples of each type mentioned above:

29) He stopped the car [because he didn't want to hit the sloth.]

30) [Although he braked hard], he couldn't avoid running into the car in front.

31) We met [while we were flying to New York.]

32) They went [wherever they could find happiness.]

33) I left early [in order that I could catch the bus.]/ [so as to catch the bus]

34) You have to study hard [if you want to pass the exams].

These clauses, as Boeckx (2012 :16-17) points out, are structures from which no element can be extracted or questioned. If sentence (29) is tested, the following ungrammatical sentences are the results:

35) a) *<Why > did he stop the car [< > he didn't want to hit the sloth?] 
b) $*<$ Who $>$ did he stop the car [because $<>$ didn't want to hit it?]

c) $*<$ What $>$ did he stop the car [because he didn't want to hit $<\quad>$ ?]

\section{Indirect Wh-question Constraint}

Kim and Sells (2007: 243) state that an indirect question is a structure, an island, from which an NP cannot be extracted.

36) a) Can you tell me [where I can find Jasmine?]

b) *Who can you tell me [where I can find < >?]

c) *Who can you tell me [where $<>$ can find Jasmine?]

Not only an NP is blocked, but also other elements, too.

37) a) I wonder [why Joseph left early.]

b) *When do you wonder [why Joseph left $<\quad>$ ?]

c) *Who do you wonder [why < > left early?]

\section{Subjacency Condition}

In 1964, Chomsky noticed that wh-movement for the purpose of forming a question or a relative clause is conditional. Only one element in the same structure can be extracted at a time. Otherwise, the result will be an ungrammatical sentence:

38) a) We know the people. We met the people in London.

b) We know the people [the people we met $<\quad>$ in London.]

c) We know the people [ who we met $<$ > in London.]

d) We know the people [we met $<$ > in London.]

The attempt to extract another element from the same structure will be abortive.

39) a) We know the people [we met $<><$ where $>$.]

b) *Where do we know the people [we met $<><$ ?] 
The Ross's work Constraints on Variables in Syntax, a thesis in 1967, was supervised by Chomsky himself. Ross examined a number of structures that prevent their elements from being extracted. Such examinations lead to the birth of a new term called "syntactic islands". Later and in 1967, Chomsky himself proposed an alternative theory called "Subjacency Condition" for Ross's observations. Chomsky suggested that an element cannot be moved across more than one "bounding node". Thus, the element where in (39b) has to move a clause boundary and a noun phrase which is impossible. Illustration (40) indicates that the element where cannot be relativized in a single movement operation; in one long jump (Baker, 1995: 597).

40)

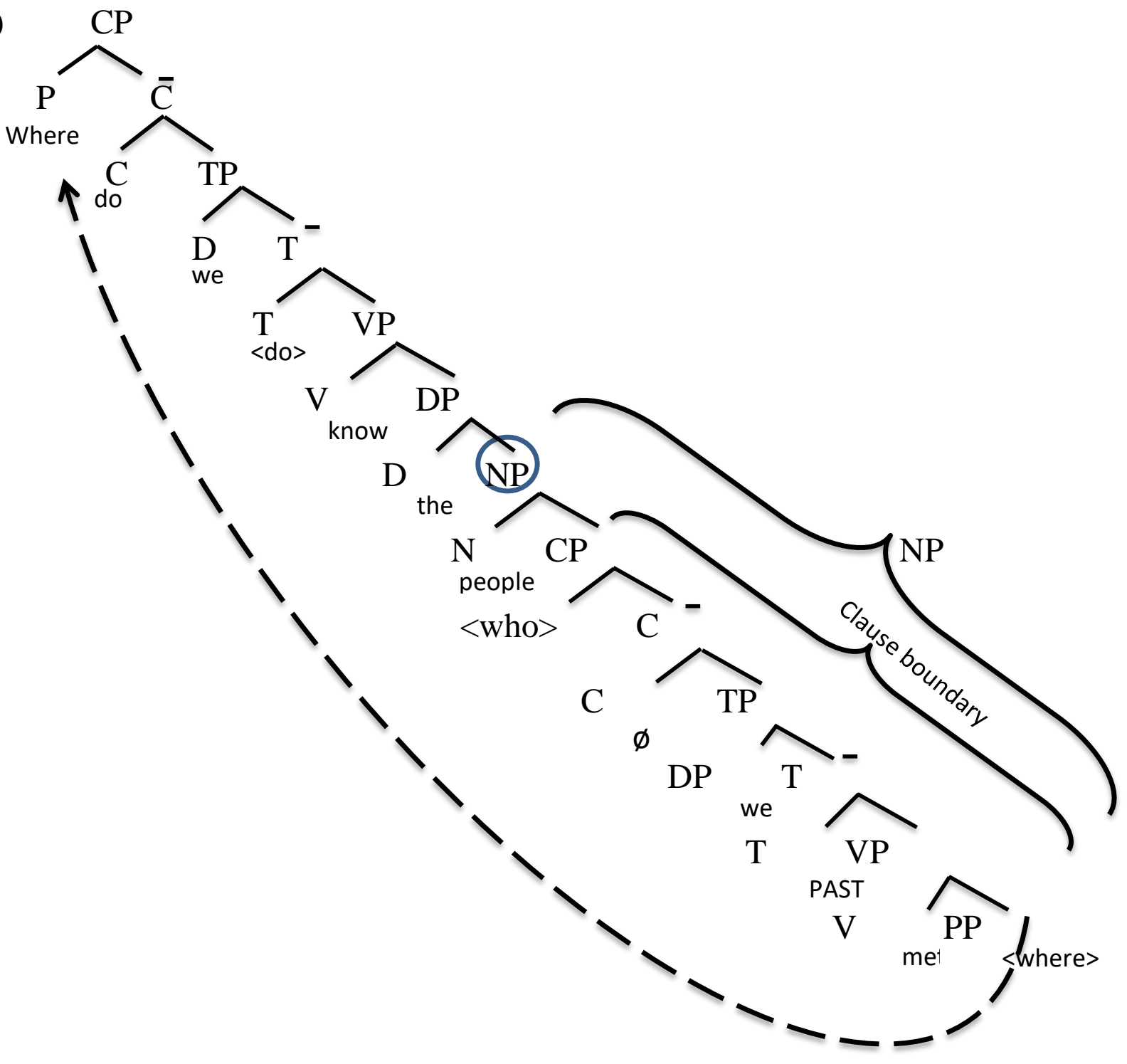

On the other hand, if we take an example of an indirect question applying "successive-cyclicity" in which a whelement can be extracted, not in one long movement operation, but in a number of short movements. In each movement, the wh-element moves to the initial position of a clause which is called "parking place".

41) I want to know [__ Jack believed that Tom said that Jane bought <what >].

I want to know [<what> Jack believed that Tom said that Jane bought $<>$ ]. 
$*<$ What $>$ do you want to know [<_> Jack believed that Tom said that Jane bought]?

42)

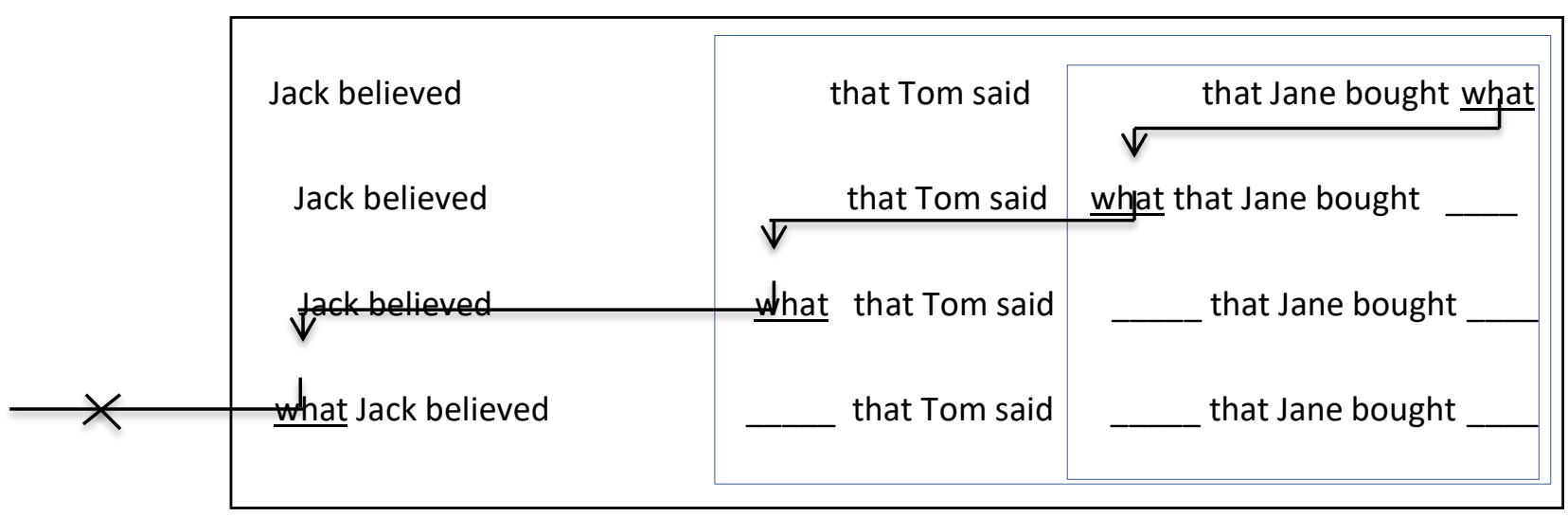

Hence, both "Subjacency Condition" and "Successive-Cyclicity" are locality principles suggested by Chomsky referring to the processes of an item that can be moved only inside the island. Finally, Hornstein (2009: 11) raises a question stating that why topicalization, relativization and the formation of interrogatives etc. are all obedient of island conditions. He answers the question pointing out that they, whatever their differences are, all include the operation of Wh/A-bar movement and this movement is subject to subjacency.

\section{Complex NP Constraints in Kurdish}

Although Mihemed (2009: 258-9) argues that, in Kurdish, it can be expected that the binding nodes are just like the English ones (NP and IP), he is not sure whether the binding nodes follow or violate the islandic constraints without testing any CNP. The underlined parts, in (43a), are a complex NP which functions as subject Ew kûrey is an NP and ke dwênê min bînim is a relative clause which post-modifies the head of the NP, kûr. No element can be extracted from the structure CNP.

43) a) [NP Ew kûrey [CP ke dwênê min bînîm] biray Azad bû.

[NP The boy [CP whom yesterday I saw]] brother Azad was.

(= The boy whom I saw yesterday was Azad's brother.)

- Extracting the head:

b) *Kê [CNP ew $<\quad>$ ke dwênê min bînîm] biray Azad bû?

In Kurdish, the interrogative pronoun "kê" (=who) in (12b) cannot be extracted. Qadir (2008: 34) states that the relative clause marker "ke" (= that/whom), in (12a), is different from the English one in that it has originally and already taken the COMP position in its deep structure. However, even though the wh-question word remains in-situ, the CNP is still the island:

c) *[CNP Ew $<$ kê> ke dwênê min bînîm] biray Azad bû? 
- Extracting the elements of the relative clause or keeping them in their places:

d) *Kê [cNp ew kûrey ke dwênê < > bînîm biray Azad bû?

e) *[cNp Ew kûrey ke dwênê <kê> bînîm biray Azad bû?

f) *Key (=when) [cNP ew kûrey ke $<>$ min bînîm] biray Azad bû?

g) *[cNp Ew kûrey ke <key> min bînîm] biray Azad bû?

When the CNP functions as direct object, the head of the NP is not directly followed by the post-modifier relative clause; the verb of the sentence occurs between the head and the relative clause:

44) a) Hikumet pêşiniyarî [NP ew piŕojeyey] kirid [CP ke ewan debê sîstimî denigdan bigoŕin].

Government a proposal [NP the project] made [CP that they should change the voting system]

- Extracting the head or keeping it in its place:

b) [çî] Hikumet pêşiniyarî kirid [CP ke ewan debê sîstimî denigdan bigớin]?

c) ? Hikumet pêşiniyarî [çî] kirid [CP ke ewan debê sîstimî denigdan bigoŕin]?

The sentence is, semantically and grammatically, correct, but the question word "çı̂" (= what) in (44c) which remains in-situ is not asking about the head of the NP, "ew piŕojeyey" (= the project), the question is about something else which is equivalent to the following question: What did the government propose to change the voting system? And this question is not about which project; it may be about anything else.

- Extracting the elements of the relative clause or keeping them in their places:

d) Kê Hikumet pêşiniyarî [NP ew piŕojeyey] kirid [ $\mathrm{CP} \mathrm{ke}<>$ debê sîstimî denigdan bigoŕin]?

e) *Hikumet pêşiniyarî [NP ew piŕojeyey] kirid [CP ke $<$ kê $>$ debê sîstimî denigdan bigoŕin]?

Although the question word ( $\mathrm{kê}=$ who), in (e), which asks about (ewan = they) remains in-situ, the interrogative sentence is incorrect. The question word is singular but the verb of the relative clause (bigorin) is plural. And if the verb is changed to a singular one, (bigorêt), the sentence loses its interrogative force which means:

f) Hikumet pêşiniyarî [NP ew piŕojeyey] kirid [CP ke $<$ kê $>$ debê sîstimî denigdan bigớêt] . (= The government proposed a motion that who changes the voting system.)

Hawkins (2004: 170) points out that CNP is a principle not a parameter opening his argument by asking a question why CNPs are less hospitable environments for gaps than other structures. On the contrary, Kuno (1973: 238-40) argues that CNPC does not apply to Japanese. For further reading (see Shopen, 2007: 224). 


\section{Sentential Subject Constraint (SSC) in Kurdish:}

In Kurdish, specified or sentential subject constraint is also an island.

45) a) [Ewey ke Dara ŕiqî le Azade] diroyekî şaxdare.

[That Dara hates Azad] is a big lie.

No element can be questioned about within this clausal subject.

b) *Kê [ewey ke Dara ríîî lêye $<\quad$ > d diroyekî şaxdare?

c) *Kê [ewey ke < > riqî le Azade] diroyekî şaxdare?

d) *Çî [ewey ke Dara $<$ > le Azade] diroyekî şaxdare?

Although wh-question words remain in-situ in Kurdish, the sentences still will be grammatically ill-formed.

e) *[Ewey ke Dara ŕiqî le $<$ kê $>$ e] diroyekî şaxdare?

f) $*[$ Ewey ke $<$ kê $>$ riqîi le Azade] diroyekî şaxdare?

g) *[Ewey ke Dara <çî̀ le Azade] diroyekî şaxdare?

\section{Left Branch Condition (LBC) in Kurdish:}

In Kurdish, the same case does not exist because the wh- question word does not move but remains in-situ. Example (46a) is an NP consisting of two branches:

46) a) Min [Np parey Azadim] dizî.

I [NP the money of Azad] stole. (= I stole Azad's money.)

b) To [çî Azadit] dizî?

c) *Çî to $[<>$ Azadit $]$ dizîi?

47) a) Azad [mindałekanî kołanekey] derkird.

b) Azad [<Kêy> kołanekey] derkird?

c) *Kê Azad [< > kołanekey] derkird?

Sentences (46a and 47a) elucidate that dependent genitive case in Kurdish is equivalent to the of-structure in English. Since Kurdish is considered as a head-last language; the head of adjective and adverb phrases occur at the end of the phrase (Khoshnaw, 2008: 32).

48) a) Hawar [AdvP zor bexêrayî] geŕayewe.

Hawar [AdvP very quickly] came back.

(= Hawar came back very quickly.) 
b) Hawar [<çenid > bexêrayî] geŕayewe?

c) *Çenid Hawar $[<$ > bexêrayî] geŕayewe?

49) a) Xanûwekey ême [Adjp zor gewreye].

House our [AdjP very big] is. (= Our house is very big)

b) Xanûwekey êwe [<çenid > gewreye]?

c) *Çenid xanûwekey êwe $[<\quad>$ gewreye $]$ ?

The difference between each pair sentences of ( $47 b \& c),(48 b \& c)$, and ( $49 b \& c)$ explain that there is no need to move the question words. It proves that question words, in Kurdish, remain in-situ. Hence it can be roughly said that LBC is not an island in Kurdish (Ma'roof, 2010: 54).

\section{Coordinate Structure Constraint (CSC) in Kurdish:}

Mihemed (2009: 257) states that whenever two NPs or two sentences are coordinated by a coordinator, they create an island from which no elements can be extracted or questioned about.

50) a) Baram [Aso û Nazdarî] bînî.

Baram [Aso and Nazdar] saw. (= Baram Saw Aso and Nazdar)

b) *Kê Baram $[<\quad>$ and Nazdarî] bînî?

c) *Kê Baram [Aso and < > bînî?

Even if the question word "Kê" (= who) remains in-situ, the result is an island:

d) *Baram $[<$ Kê $>$ û Nazdarî] bînî?

e) *Baram [Aso û <Kêy>] bînî?

On the contrary, Fatah (2010: 74) argues that the clauses in compound sentences that are coordinated buy the coordinator " $\hat{u}$ " (= and) are equivalent. He also adds that only the verb in the first part of the conjunct cannot be questioned when they semantically have a strong relation:

51) a) [Kameran gwêzekanî deweşand] û [mindałekanîş koyan dekirdnewe].

[Kameran the nuts was shaking] and [the children were collecting them].

b) *[Kameran <çî dekird $>$ ] û [mindałekanîş koyan dekirdnewe $]$ ?

c) $[<\mathrm{Kê}>$ gwêzekanî deweşand] û [mindałekanîş koyan dekirdnewe]?

d) [Kameran gwêzekanî deweşand] û $[<$ Kê $>$ koy dekirdnewe]? 
e) [Kameran gwêzekanî deweşand] û [mindałekanîş < çîyan dekird>]?

Sentence (51a) means that someone was shaking the nut tree so that the nuts fell down and the children were collecting them. So only (51b) is ungrammatical or it creates an island. There are two actions that were happening one after the other or may be at the same time. Asking about the first action is not grammatical because the speaker does not understand the second part unless the verb of the first part is quite clear. On the other hand, asking about any other elements does not lead to the creation of an island. However, when the conjuncts are coordinated buy "yan" (=or), there will be a sense of choice between the two conjuncts:

52) a) [Nanî nîweŕo] yan [nanî êware] pêkewe dexoyn.

[Lunch] or [dinner] together we will have.

(= We will have lunch or dinner together)

b) $*[<$ Çî̀ $>$ yan [nanî êware] pêkewe bixoyn?

c) *[<Çî nîweŕo $>]$ yan [nanî êware] pêkewe bixoyn?

d) $*[<$ Nanî key $>]$ yan [nanî êware] pêkewe bixoyn?

e) $*[<$ Nanî key $>$ ] yan [nanî êware] pêkewe bixoyn?

f) *[Nanî nîweŕo] yan [<çî> êware] pêkewe bixoyn?

Concerning the coordinator "bełam" (=but), Mihemed (2009: 257) adds that the conjuncts are islands, too.

53) a) Ewey ke [Azad minałekani xoşdewêt] bełam [Newzad minałekani xoşnawêt] lay hemwan ŕûne.

That Azad likes the children but Newzad doesn't like them is obvious.

b) *Ewey ke key [Azad $<$ > xoşdewêt] bełam [Newzad minałekani xoşnawêt] lay hemwan rúne?

c) *Ewey ke kê $[<\quad>$ minałekani xoşdewêt] bełam [Newzad minałekani xoşnawêt] lay hemwan ŕune?

Although Mihemed has not tested the examples ( $53 \mathrm{~b}$ or c) whether they still create an island or not when the question word "kê" (=who) remains in-situ, they give the same result; they are islands in Kurdish, too.

d) *Ewey ke [Azad $<$ key $>$ xoşdewêt] bełam [Newzad minałekani xoşnawêt] lay hemwan rúne?

e) *Ewey ke $[<$ kê> minałekani xoşdewêt] bełam [Newzad 
minałekani xoşnawêt] lay hemwan ŕune?

Even co-ordinate structures like Azad û Ali are islands if one wants to tropicalize a part of the coordinate structure. Hence, in a sentence like:

54) Min sersamim be Azad $\hat{u}$ Ali.

The whole co-ordinate structure Azad $\hat{u}$ Ali can be moved to the front of the overall sentence (as in 'Azad $\hat{u}$ Ali, min sersamim pêyan), but $A z a d$ cannot be topicalised alone (as we see from the ungrammaticality of (56)

56) $*$ Azad $\min$ sersamim William $\hat{u}$. (Radford, 2009: 391)

\section{Adjunct Clause Constraint in Kurdish}

In Kurdish, elements of adjunct clauses are constrained from extraction, too.

55) a) Aram naçête derewe [çûnke deyewêt xoy le nexoşî biparêzêt].

Aram doesn't go out because he wants to protect himself from disease.

b) *Boçî Aram naçête derewe $[<\quad>$ deyewêt xoy le nexoşî biparêzêt $]$ ?

c) *Le çî Aram naçête derewe [çûnke deyewêt xoy< > biparêzêt]?

When the question words remain in-situ, the result will be the same:

d) *Aram naçête derewe $[<$ boçî $>$ deyewêt xoy le nexoşî biparêzêt $]$ ?

e) *Aram naçête derewe [çûnke deyewêt xoy $<$ Le çî> biparêzêt]?

The reason for the islandhood in both Kurdish and English is that only the elements of superordinate clauses can be extracted, but the elements of subordinate clauses do not allow this extraction. In Kurdish, the subordinate clause, in a complex sentence, can be easily recognized. That reason is that the clause marker "ke" is equivalent to almost all English clause markers of ajunct and relative clauses such as 'where', 'when', 'why', 'who(m)', 'which', 'that', etc. (Mukiryanî, 2004: 10).

\section{Indirect Wh-question Constraint in Kurdish}

Mihemed (2009: 255) refuses the statement of other linguists stating that sentences (56b, c \& d) are still grammatical because moving the question word has not crossed more than one bounding node; the question word has moved across only one (IP) node. The evidence for their claim is that moving wh-question phrase does not exist in Kurdish or Persian. He provides two evidences for his statement. Firstly, Kurdish has its own direct questions like (57b, c \& d), and indirect questions like $(58,59,60 \& 61)$ :

56) a) Baram dezanêt [kê gûłekan aw dedat].

Baram knows who the flowers waters

(= Baram knows who waters the flowers)

b) *Kê Baram dezanêt $[<\quad>$ gûłekan aw dedat $]$ ?

c) * Baram dezanêt [gûłekan $<$ kê $>$ aw dedat]?

d) * Gûłekan Baram dezanêt $[<\mathrm{kê}>$ aw dedat $]$ ?

57) a) Akam gûłî pêşkeş be Sakar kirid.

b) <Kê> gûłî pêşkeş be Sakar kirid? 
c) Akam <çî̀ pêşkeş be Sakar kirid?

d) Akam gûlî pêşkeş be $<$ kê $>$ kirid?

58) Aram pirsî [Akam <çî̀ pêşkeş be Sakar kirid]?

59) Aram gutî [Akam gûłî pêşkeş be <kê> kirid?]?

60) [Aram dezanêt [Akam gûłî pêşkeş be <kê> kirid]]?

61) [Aram [wîstî [PRo bizanêt [kê gûłî da be kê]]]?

Secondly, in Kurdish, the interrogative pronoun does not have the interrogative force as a question word, and sentences (60 \& 61) do not have interrogative elements. So a question word cannot be recognized as a variable in Kurdish, that's why it does not represent or show the phenomenon of subjacency condition. Interrogative sentences are formed by virtue of stress and intonation without needing any question words and moving them to the front of the sentence. Extracting the wh-question words, in all the sentences $(58,59,60$, and 61), results in islandhood.

62) *Çî Aram pirsî [Akam < > pêşkeş be Sakar kirid]?

63) *Kê Aram gutî [Akam gûłî pêşkeş be $<$ > kirid?]?

64) *Kê [Aram dezanêt [Akam gûłî pêşkeş be $<\quad>$ kirid]]?

65) *Kê [Aram [wîstî [pro bizanêt $[<>$ gûłî da be kê]]]?

\section{Conclusions}

Complex noun phrase and sentential subjects in Kurdish create islandic structures, if the wh-question words are moved to the front of the sentence or remain in-situ.

Left branch condition and indirect wh-questions in Kurdish are controversial; any attempt at extracting and whquestioning the left branch of an NP or of indirect wh-questions is island in Kurdish but keeping it in its place will not lead to the creation of any constraints.

Coordinate constraint and adjunct clauses structures in Kurdish are also islands without taking the movement of the wh-question word into account. 


\section{List of Kurdish Phonemic Symbols}

\section{1- Kurdish Consonants}

\begin{tabular}{|c|c|c|}
\hline /p/ pêkewe & /pekəwə/ & 'together' \\
\hline /b/ beyanî & /bəja:ni:/ & 'morning' \\
\hline /t/ temen & /təmən/ & 'age' \\
\hline /d/ desit & /dəst/ & 'hand' \\
\hline /k/ bêkar & /bekar/ & 'jobless' \\
\hline /g/ gerdûn & /gərdu:n/ & 'universe' \\
\hline /q/ qeyran & /qəjræn/ & 'crisis' \\
\hline /२/ ewe & /Rəwə/ & 'that' \\
\hline /f/ farisî/ & /farısi:/ & 'Persian' \\
\hline /v/ mirov & /mirnv/ & 'human' \\
\hline /s/ sêşem & $/$ se $\int ə m /$ & 'Tuesday' \\
\hline |z/ zewî & /zəwi:/ & 'Earth' \\
\hline /f/ şanişîn & 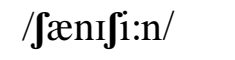 & 'kingdom' \\
\hline /3/ jûr & /zu:r/ & 'room' \\
\hline$|\chi|$ xewin & /Xəwin/ & 'sleep' \\
\hline$/ y /$ ẍerîbe & /yəri:bə/ & 'stranger' \\
\hline$/ \mathbf{h} /$ hewşe & /həw」ə/ & 'yard' \\
\hline /h/ hêlke & /helkə/ & 'egg' \\
\hline /S/ 'ereb & / Sərəb/ & 'Arab' \\
\hline /h/ hêz & /hez/ & 'power' \\
\hline /t $\mathbf{f} /$ çetir & /t $\int \partial t ı r /$ & 'umbrella' \\
\hline /dz/ ciwan & /dzıwæn/ & 'beautiful' \\
\hline /l/ lêw & /lew/ & 'lip' \\
\hline [ł] galte & [ga:ttə] & 'joke' \\
\hline$/ \mathbf{m} /$ mirdin & /mirdin/ & 'death' \\
\hline /n/ nerim & /nərım/ & 'soft' \\
\hline$/ \mathrm{r} /$ piris & /pirIs/ & 'issue' \\
\hline [r] 'rêrew & [rerəw] & 'corridor' \\
\hline $\begin{array}{l}\text { /w/ hewir } \\
\text { /j/ peywendî }\end{array}$ & /how Ir/ & 'cloud' \\
\hline
\end{tabular}

\section{2- Kurdish Vowels}

$\begin{array}{llll}\text { /i:/ } & \text { sîr } & \text { /si:r/ } & \text { 'garlic' } \\ \text { /i/ } & \text { xiwardi } & \text { /xwa:rdi/ } & \text { 'he ate' } \\ \text { /r/ } & \text { mirdin } & \text { /mrrdın / } & \text { 'death' } \\ \text { /e/ } & \text { sê } & \text { /se/ } & \text { 'three' } \\ \text { /ə/ } & \text { hefte } & \text { /həftə/ } & \text { 'week' } \\ \text { /a:/ } & \text { dar } & \text { /da:r/ } & \text { 'wood' } \\ \text { /o/ } & \text { kurt } & \text { /kort/ } & \text { 'village' } \\ \text { /u:/ dûr } & \text { /durr/ } & \text { 'far' }\end{array}$




\section{بلهربهسته دووركهيبيكان له زمانى نينكليزى و كوريليدا}

\section{برهان قادر سليم}

بهشى زمانى ئينكليزى، كوليزى بِهوهردهى بنهرهت، زانكوى رِايهرين، رِانيه، هـريّمى كوردستان، عيراق.

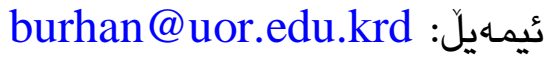

له رِيزمانى كواستنهوهيى دا ، جههند ياسايهكى وهك دهرهينان و كواستنهوه و بِرسياركردن و رِتهى باسمهند هـن

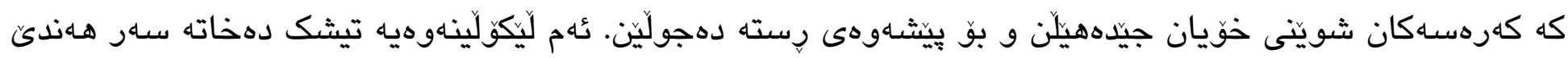
له دوركه سينتاكتيكيهكان له زمانى ئينكليزى و كورديدا و تاقيكردنهوهيان ئاخو ئهم دوركانه بهربهست دهخهنه بهردهم هينانهدهرهوه و كواستناوهى كهرهستهكانيان له زمانى كورديدا ياخود نا. لهم ليكوَّلينهوهيهدا ، كريمانهى ئهوه دهكريت كه دوركه تهنها دهربارهى ئهو بهربهاستانه نين لهبهردهم دهرهينان و كواستناوهى كهرهستهيهك بو سهردتاى رِتها.

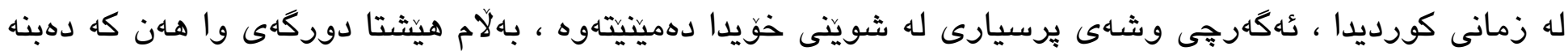
بهاربهت له دروستكردنى ههنديّ رِّنانى رِيّزمانى ، بوّ نمونه ، رِستهى بِرسيارى.

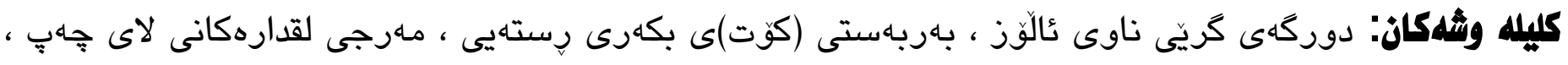

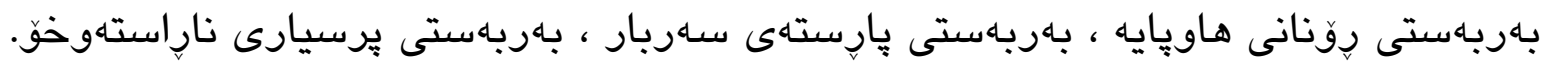




\section{References:}

Baker, C. L. (1995). English Syntax. Cambridge, Mass.: MIT Press.

Baltin, M. and Collins, C. (2001). The Handbook of Contemporary Syntactic Theory. Oxford: Blackwell Publishers Ltd.

Boeckx, C. (2012). Syntactic Islands. Cambridge: Cambridge University Press.

Chomsky, N. (1964). Current Issues in Linguistic Theory. The Hague: Mouton.

Coene, M. and D'hulst, Y. (2003). From NP to DP: Volume 1: The syntax and Semantics of Noun Phrases.

Amsterdam / Philadelphia: John Benjamins Publishing Company.

Frank, R. (2002). Phrase Structure Composition and Syntactic Dependencies. Cambridge, Mass.: MIT Press.

Featherston, S. (2001). Empty Categories in Sentence Processing. Amsterdam / Philadelphia: John Benjamins Publishing Company.

Goodluck, H. and Rochemont, M. (1992). Island Constraints: Theory, Acquisition and Processing. Berlin: Springer Science + Business Media Dordrecht.

Hawkins, J. A. (2004). Efficiency and Complexity in Grammars. Oxford: Oxford University Press.

Heck, F. (2008). On Pied-Piping: Wh-Movement and Beyond. Berlin: Mouton de Gruyter.

Hornstein, N. (209). A Theory of Syntax: Minimal Operations and Universal Grammar. Cambridge: Cambridge University Press.

Johnson, K. (2004). Introduction to Transformational Grammar.

Johnson, K. (2008). Topics in Ellipsis. Cambridge: Cambridge University Press.

Kaplan, R. M. and Zaenen, A. (1989). Long-Distance Dependencies, Constituent Structure, and Functional Uncertainty. Chicago: University of Chicago Press.

Kim, J. and Sells, P. (2007). English Syntax: An Introduction. Stanford: CSLI Publications

Kuno, Susumo. (1973). The Structure of the Japanese Language. Cambridge: MA: MIT Press.

Lapping, S. and Benmamoun, E. (1999). Fragments: Studies in Ellipsis and Gapping. Oxford/New York: Oxford University Press. 
Newson, M., Hordós, M., Pap, D., Szecsenyi, K., Toth, G., and Vincze, V. (2206). Basic English Syntax with Exercises. Pudapest: Bolcsesz Konzorcium.

Quirk, R., Greenbaum, S., Leech, G. and Svartvik, J. (1985). A Comprehensive Grammar of the English Language. London \& New York: Longman Group Limited.

Radford, A. (2004). Minimalist Syntax: Exploring the Structure of English. Cambridge: Cambridge University Press. Radford, A. (2009). An Introduction to English Sentence Structure. Cambridge: Cambridge University Press.

Ross, J. R. (1967). Constraints on Variables in Syntax. Unpublished PhD diss. Massachusetts Institute of Technology.

Sag, I. A. and Wasow, T. (1999). Syntactic Theory: A Formal Introduction. Stanford: CSLI Publications.

Shopen, T. (2007). Language Typology and Syntactic Description. Cambridge: Cambridge University Press.

Fatah, M. M. (2010). Lêkołînewe Zimanewanîyekan. Hewlêr: Çapxaney Ŕojhelat.

Kanebî, D. S. (2015). Tîyorî Barge Xistin û Ŕonanî Ŕiste. Hewlêr: Mukiryan.

Khoshnaw, K. A. (2008). Berkar le Zimanî Kurdîda bepey Ŕebazî Fớmî. Hewlêr: Çapxaney Wezaretî Roşinbîrî.

Me’roof, A. M. (2010). Dirûstey Firêz le Zimanî Kurdîda. Sulaimanî: Mełbendî Kurdology.

Mihemed, H. W. (2009). Peywendîye Ronanîyekanî Niwandine Sîntakîyekan. Hewlêr: Çapxaney Ŕojhelat.

Mukiryanî, K. (2204). Sîntakisî Ŕistey Têkeł. Hewlêr: Aras.

Qadir, K. O. (2008). Ŕistey Basmenid le Zimanî Kurdîda. Sulaimanî: Mełbendî Kurdology. 